\title{
Assessment of Sugarcane Genotypes for Cane Yield
}

\author{
Amjad Ali ${ }^{*}$, Sher Aslam Khan ${ }^{2}$, Abid Farid ${ }^{2}$, Ayub khan ${ }^{2}$, Shah Masaud Khan ${ }^{2}$ and Naushad Ali ${ }^{2}$
}

${ }^{1}$ Sugar Crops Research Institute Mardan, Pakistan; ${ }^{2}$ Department of Agricultural Sciences, University of Haripur, Haripur, Pakistan.

\begin{abstract}
Fourteen sugarcane genotypes and two check cultivars were evaluated in randomizedcomplete block design with three replications at Sugar Crops Research Institute Mardan during 2012-13 and 201314. The studies were conducted in two plant crops to calculate broad sense heritability (repeatability), genetic gain and correlations among the parameters, and establish selection criteria.Highly significant ( $\mathrm{p} \leq$ 0.01) differences were found among the genotypes for number of tillers, plant height, cane length,number of nodes, internodes length,number of millablecane and cane yield while non-significant differences were recorded for cane diameter. The effect of genotype and crop interaction was highly significant fornumber of tillers while non-significant for other characters. Broad sense heritability for different characters showed varying levels and it was higher for internodes length (43\%), number of nodes (39\%),cane length (39\%), plant height (30\%), number of tillers (12\%), cane yield (41\%) andnumber of millablecane (35\%), respectively indicating that these traits could be selected in the improvement of crop yield. Genetic gain was higher for cane length $(36.53 \mathrm{~cm})$, plant height $(31.84 \mathrm{~cm})$ and number of tillers $\left(12.98\right.$ tillers per $\left.9 \mathrm{~m}^{2}\right)$. Number of tillers $\left(r_{g}=0.96, r_{p}=0.83\right)$, plant height $\left(r_{g}=0.95, r_{p}=0.81\right)$, cane length $\left(r_{g}=0.90, r_{p}=0.76\right)$, number of nodes $\left(r_{g}=0.79, r_{p}=0.67\right)$, internodes length $\left(r_{g}=0.80, r_{p}=0.74\right)$ and number of millablecane $\left(r_{g}=0.96, r_{p}=\right.$ 0.87) exhibited highly significant and positive correlation with cane yield at genotypic and phenotypic levels.

Received | March 29, 2017; Accepted | October 23, 2017; Published | November 18, 2017

*Correspondence | Amjad Ali, Sugar Crops Research Institute Mardan, Pakistan; Email: amjad_pbg@yahoo.com

Citation | Ali, A., S.A. Khan, A. Farid, A. khan, S.M. Khan and N. Ali.2017. Assessment of sugarcane genotypes for cane yield. Sarhad Journal of Agriculture, 33(4): 668-673.

DOI | http://dx.doi.org/10.17582/journal.sja/2017/33.4.668.673

Keywords | Sugarcane, Heritability, Correlation, Selection, Cane yield
\end{abstract}

\section{Introduction}

Qugarcane (Saccharum officinarum L.) is an important cash crop (Falcon, 1964). Sugarcane varieties tend to run out or decline after some years in a specific area (Khan et al., 2009). To obtain high yield on sustainable basis, it has been essential to substitute varieties regularly with new clones. The sugarcane varieties is clonally propagated and is not expected to undergo genetic change as occur in a seed propagated crop though the variety decline occurs due to disease incidence and thus need to be replaced (Poehlman,1959). In Pakistan due to low yield condition it has been necessary to develop sugarcane varieties with high cane and sugar yield (Baloch et al., 2002; Arain et al., 2011). It is important that the germplasm must contain sufficient amount of variations for the varietal development program (Chaudhary, 2001). Like other vegetatively propagated crops introduction and clonal selection have been the principal breeding procedures and are playing an important role in varietal development program at SCRI Mardan, Khyber Pakhtunkhwa (Tahir et al., 2013). In any breeding population, there are genetic alterations present and these variations are the basic mechanisms to develop selection and breeding approaches that eventually 
lead to better genetic gains. In the selection procedure, identification and separation of the dependent and independent characters are important. For a successful selection program developmental criterion is mandatory. Genotypes with better yield and quality parameters and broader adoptability can be selected and suggested for farming. Repeatability (broad sense heritability) and genetic gains study can be largely used for a good breeding programs study (Chaudhary, 2001). The characters with higher repeatability and genetic gain can be used for selection. The correlations among various characters with yield and their mutual correlation study is important and also gives an insight between the parameters relation (Kang et al., 1983).

Based on the above facts, the present research study was designed to evaluate the genotypes through repeatability, estimated genetic gain and path coefficient analysis. This will help understand the importance of genetic potential of various growth, cane, and yield traits. It will help in developing a selection criterion for sugarcane breeding programs in Khyber Pakhtunkhwa, Pakistan.

\section{Materials and Methods}

The study was conducted at the SCRI, Mardan, located at $34^{\circ}$ North latitude and $72^{\circ}$ East longitude, altitude 283 meter, total rainfall $696 \mathrm{~mm}$ (summer $488 \mathrm{~mm}$, winter $208 \mathrm{~mm}$ ), summer mean temperature $39.8^{\circ} \mathrm{C}$, winter mean temperature $1.33^{\circ} \mathrm{C}$ with a mean relative humidity of $60.8 \%$ Pakistan onsugarcane plant crop during 2012-13 and 2013-14. Materials comprised 14 sugarcane genotypes and two check cultivars (Table 1) arranged in a randomized complete block design with three replications. These genotypes were advanced from previous selection stages with diverse origins. A plot for each genotype was $10 \mathrm{~m}$ long and $6.7 \mathrm{~m}$ wide, having 7 rows (150 buds per row) with a row-to-row distance of $90 \mathrm{~cm}$. Recommended dose of fertilizer i.e. $\mathrm{N}, \mathrm{P}_{2} \mathrm{O}_{5}$ and $\mathrm{K}_{2} \mathrm{O}$ at rates of 150: 100:100 was given to the crop. Data were recorded, on the following growth, cane and yield charactersof sugarcane.

\section{Growth traits}

Data on number of tillers was recorded by counting numbers of tillers in the central row having 10 meter length in each plot.
The data on plant height wererecorded on five randomly selected plants with the help of a tap in centimeters and then were averaged.

Table 1: List of sugarcane genotypes and their sources.

S. No. Genotype Source

1. MS-2000-Ho-535 Houma, Louisiana, USA

2. MS-99-Ho-6 Houma, Louisiana, USA

3. MS-2000-Ho-115 Houma, Louisiana, USA

4. MS-2000-Ho-357 Houma, Louisiana, USA

5. S-98-SSG-363 Guatemala

6. S-98-SSG-612 Guatemala

7. MS-91-CP-248 Canal Point, USA

8. MS-91-CP-249 Canal Point, USA

9. S-92-US-72 Canal Point, USA

10. MS-91-CP-523 Canal Point, USA

11. MS-92-CP-99 Canal Point, USA

12. MS-2000-Ho-360 Houma, Louisiana, USA

13. MS-2003-HS-274 Habib Sugar Mill Research Farm, Sindh, Pakistan

14. MS-2003-HS-366 Habib Sugar Mill Research Farm, Sindh, Pakistan

15. CP-77/400 Check cultivar

16. Mardan-93 Check cultivar

\section{Cane traits}

Five plants were selected at randomin each genotype. The trash was removed and the length in centimeters was measured in the month of October and the average lengths were noted.

Number of nodes was recorded by counting nodes in 5 plants taken in random for each genotype and were averaged.

Data on internode length was determined by measuring internodes length of the $5^{\text {th }}$ internode from the baseof five randomly selected stalks and then averaged.

Cane diameter of the stalk was measured usingdigital Vernier Caliper (0-150mm digital caliper. Stainless Hardened. Germany)for each of the 5 randomly selected stalk at the $5^{\text {th }}$ internode from the base.

\section{Yield traits}

Number of millablecane was taken by counting the number of millablecane in the mid row (without the undeveloped tillers). 
Table 2: Mean squares of growth, cane and yield traits of sugarcane genotypes.

\begin{tabular}{|c|c|c|c|c|c|c|c|c|c|}
\hline Source & DF & $\begin{array}{l}\text { Number of } \\
\text { tillers }\end{array}$ & Plant height & Cane length & $\begin{array}{l}\text { Number of } \\
\text { nodes }\end{array}$ & $\begin{array}{l}\text { Internodes } \\
\text { length }\end{array}$ & $\begin{array}{l}\text { Cane diam- } \\
\text { eter }\end{array}$ & $\begin{array}{l}\text { Number of milla- } \\
\text { blecane }\end{array}$ & Can \\
\hline Crops & 1 & $76444.6^{* *}$ & $70.04^{\mathrm{ns}}$ & $0.17^{\mathrm{ns}}$ & $0.0104^{\mathrm{ns}}$ & $4.99594^{\mathrm{ns}}$ & $1.041^{\mathrm{ns}}$ & $189.844^{\star}$ & $81.126^{*}$ \\
\hline Reps(Crops) & 4 & 1129.9 & 226.2 & 58.58 & 6.9583 & 4.22937 & 0.00891 & 24.74 & 40.683 \\
\hline Genotypes & 15 & $4833^{\star *}$ & $4336.92^{\star *}$ & $3940.6^{* *}$ & $21.0438^{\star *}$ & $9.86555^{\star *}$ & $0.01681^{\mathrm{ns}}$ & $248.327^{\star *}$ & $102.772^{\star *}$ \\
\hline $\begin{array}{l}\text { Crops x Geno- } \\
\text { types }\end{array}$ & 15 & $3407.594^{\star *}$ & $855.01^{\mathrm{ns}}$ & $400.86^{\mathrm{ns}}$ & $3.6326^{\mathrm{ns}}$ & $1.54683^{\text {ns }}$ & $0.00632^{\mathrm{ns}}$ & $75.266^{\mathrm{ns}}$ & $19.984^{\mathrm{ns}}$ \\
\hline Error & 60 & 831 & 1570.4 & 1168.0 & 5.003 & 1.9417 & 0.0116 & 43.85 & 20.05 \\
\hline CV\% & & 12.94 & 19.72 & 20.90 & 17.08 & 9.49 & 11.50 & 8.44 & 5.79 \\
\hline
\end{tabular}

Table 3: Basic statistics of 16 sugarcane genotypes evaluated as plant crops at SCRI, Mardan.

$\begin{array}{lllllll}\text { Traits } & \text { Mean } & \boldsymbol{\delta}^{\mathbf{2}} & \boldsymbol{\delta} & \text { Minimum } & \text { Maximum } & \boldsymbol{\delta}^{\mathbf{2} \text { as \% of mean }} \\ \text { Number of Tillers } & 222.70 & 805.50 & 28.38 & 163.33 & 287.50 & 361.70 \\ \text { Plant Height (cm) } & 200.98 & 722.82 & 26.89 & 164.17 & 273.33 & 359.65 \\ \text { Cane length (cm) } & 163.50 & 656.77 & 25.63 & 122.00 & 240.00 & 401.69 \\ \text { Number of nodes } & 13.09 & 3.51 & 1.87 & 9.50 & 18.00 & 26.79 \\ \text { Internodes length (cm) } & 14.69 & 1.64 & 1.28 & 12.28 & 16.57 & 11.19 \\ \text { Cane diameter (cm) } & 0.94 & 0.00 & 0.05 & 0.83 & 1.03 & 0.30 \\ \text { Number of millablecane } & 78.45 & 41.39 & 6.43 & 65.67 & 94.67 & 52.76 \\ \left.\text { Cane yield (tha }{ }^{-1}\right) & 77.39 & 17.13 & 4.14 & 70.33 & 88.33 & 22.13\end{array}$

Data on cane yield was taken by weighing the cane without trash per plot in kilograms and converted in to tonsha ${ }^{-1}$ by using the following formula.

$$
\text { Caneyield }=\left(\frac{x \times 10000}{\text { plot size } X 1000}\right)
$$

Where;

$x$ : yield in $\mathrm{kg}$ per plot (Tahir et al., 2014a).

Heritability was worked using the mean squares(Singh et al., 1993). Genetic advance was estimated for important traits using 10\% selection intensity (Johnson et al., 1955):

Where;

$$
\text { Genetic gain }=\mathrm{K} \times \sigma_{\mathrm{p}} \times \mathrm{h}^{2}
$$

K: 1.75 at $10 \%$ selection intensity; $\sigma_{p}$ : Phenotypic standard deviation; $h^{2}$ : Heritability.

PLABSTAT version 3A (Utz, 2011) was used to determine correlations at phenotypic and genotypic levels. Standard errors for both correlations were calculated as defined by Mode and Robinson (1959).

\section{Results and Discussion}

Statistical analysis

Mean squares pertaining to crops were highly signif- icant for number of tillers, significant for number of millablecane and cane yield while non-significant for the remaining characters (Table 2). Similarly, among genotypes highly significant differences were present for number of tillers, plant height, cane length, number of nodes, internodes length, number of millablecane and cane yield while non-significant for cane diameter. The effect of genotype and crop interaction was found non-significant for all parameters except number of tillers.

\section{Basic statistics of all the parameters}

The number of tillersper row ranged from 163.33to 287.50 with mean value of 222.69. Plant height ranged from $164.16 \mathrm{~cm}$ to $273.33 \mathrm{~cm}$ with a mean value of $200.98 \mathrm{~cm}$, (Table 3). Cane length ranged from 122 $\mathrm{cm}$ to $240 \mathrm{~cm}$ with mean value of $163.5 \mathrm{~cm}$. Number of nodes ranged from 9.5 to 18 with mean value of 13.09. Internodes length ranged from $12.28 \mathrm{~cm}$ to $16.56 \mathrm{~cm}$ with mean value of $14.69 \mathrm{~cm}$. Cane diameter ranged from $0.83 \mathrm{~cm}$ to $1.03 \mathrm{~cm}$ with mean value of $0.93 \mathrm{~cm}$. The number of millablecane ranged from 65.66 to 94.66 with mean value of 78.45 while cane yield ranged from 70.33 to $88.339 \mathrm{t} \mathrm{ha}^{-1}$ with mean of $77.38\left(\mathrm{t} \mathrm{ha}^{-1}\right)$. Higher variance and standard deviation was shown by tillering (805.50 and 28.38), plant height (722.82 and 26.89) and cane length (656.77 and 25.63). Almost similar trend was found in these characters as means of percentof variance. 
Table 4: Variances, heritability and expected genetic gain for growth, cane and yield traits of sugarcane genotypes.

$\begin{array}{llllll}\text { Traits } & \mathbf{V}_{\mathbf{g}} & \mathbf{V}_{\mathbf{g x c}} & \mathbf{V}_{\mathbf{e}} & \mathbf{h}^{2} & \text { Exp. GG } \\ \text { Number of tillers } & 237.56 & 858.86 & 831 & 0.12 & 12.98 \\ \text { Plant height }(\mathrm{cm}) & 580.31 & -238.45 & 1570.37 & 0.30 & 31.84 \\ \text { Cane length }(\mathrm{cm}) & 589.95 & -255.72 & 1168.03 & 0.39 & 36.53 \\ \text { Number of nodes } & 2.90 & -0.456 & 5.00 & 0.39 & 2.55 \\ \text { Internodes length }(\mathrm{cm}) & 1.38 & -0.131 & 1.94 & 0.43 & 1.86 \\ \text { Cane diameter }(\mathrm{cm}) & 0.0017 & -0.0017 & 0.0115 & 0.15 & 0.04 \\ \text { Number of millablecane } & 28.84 & 10.47 & 43.85 & 0.35 & 7.59 \\ \text { Cane yield }\left(\mathrm{t} \mathrm{ha}^{-1}\right) & 13.798 & -0.022 & 20.052 & 0.41 & 5.69\end{array}$

Table 5: Phenotypic (above diagonal) and genotypic (below diagonal) correlations among growth, cane and yield characters of sugarcane genotypes.

\begin{tabular}{|c|c|c|c|c|c|c|c|c|}
\hline & $\begin{array}{l}\text { Number of } \\
\text { tillers }\end{array}$ & $\begin{array}{l}\text { Plant } \\
\text { height }\end{array}$ & $\begin{array}{l}\text { Cane } \\
\text { length }\end{array}$ & $\begin{array}{l}\text { Number of } \\
\text { nodes }\end{array}$ & $\begin{array}{l}\text { Internodes } \\
\text { length }\end{array}$ & Cane diameter & $\begin{array}{l}\text { Number of } \\
\text { millablecane }\end{array}$ & Cane yield \\
\hline Number of Tillers & 1 & $0.77^{* *}$ & $0.74^{* *}$ & $0.68^{* *}$ & $0.81^{* *}$ & 0.29 & $0.86^{* *}$ & $0.83^{* *}$ \\
\hline Plant height & $0.93++$ & 1 & $0.93^{* *}$ & $0.78^{* *}$ & $0.80^{* *}$ & 0.44 & $0.84^{* *}$ & $0.81^{* *}$ \\
\hline Cane length & $0.86++$ & $0.99++$ & 1 & $0.85^{* *}$ & $0.72^{* *}$ & 0.27 & $0.79^{* *}$ & $0.76^{\text {*** }}$ \\
\hline Number of nodes & $0.81++$ & $0.91++$ & $0.97++$ & 1 & $0.62^{* *}$ & 0.43 & $0.67^{* *}$ & $0.67^{* *}$ \\
\hline Internodes length & $0.93++$ & $0.92++$ & $0.79++$ & $0.69++$ & 1 & $0.51^{*}$ & $0.78^{* *}$ & $0.74^{* *}$ \\
\hline Cane diameter & 0.41 & $0.60+$ & 0.23 & $0.56+$ & $0.75+$ & 1 & 0.41 & 0.26 \\
\hline Number of millablecane & $0.98++$ & $0.99++$ & $0.92++$ & $0.74++$ & $0.89++$ & $0.62+$ & 1 & $0.87^{* *}$ \\
\hline Cane yield & $0.96++$ & $0.95++$ & $0.90++$ & $0.79++$ & $0.80++$ & 0.39 & $0.96++$ & 1 \\
\hline
\end{tabular}

Repeatability (Broad Sense Heritability) and genetic gain

Heritability showed the effectiveness of selection, the breeding method adopted and response of various traits under a particular selection pressure (Jamoza et al., 2014). Genetic gain is the measure which predicts gain from selection. Higher genetic gain results in higher probability of selecting individuals with better performance (Tahir et al., 2014 b). The values of the environmental variances were larger than genetic variances for almost all the parameters studied (Table 4). High broad sense heritability was recorded for internodes length (43\%), cane yield (41\%), number of nodes (39\%), cane length (39\%) and number of millablecane (35\%). Higher genetic advances were noted for cane length $(36.53 \mathrm{~cm})$, plant height $(31.84 \mathrm{~cm})$ and number of tillers (12.98 tillers per $9 \mathrm{~m}^{2}$ ).

\section{Correlation}

All parameters except quality traits showed positive and highly significant correlation both at phenotypic and genotypic levels with cane yield (Table 5). The highest phenotypic correlation was shown by number of millablecane (0.87), number of tillers (0.83) and plant height (0.81) while the highest genotypic corre- lation was shown by number of tillers (0.96), number of millablecane (0.96), plant height (0.95) and cane length (0.90), respectively. Cane diameter was positively associated with cane yield at both the levels and its association was lower than other cane parameters.

The significant genotypic effects showed that there are sufficient variability among the genotypes and the possibility of genetic improvement (Punia, 1982; Khan et al., 2004). The relatively large genotypic mean squares showed that clones have a broader background and differed in their potential for the individualities. Significant crops interactions for number of tillers, number of millablecane and cane yield showed that mean performances of the genotypes were influenced by $1^{\text {st }}$ and $2^{\text {nd }}$ plant crop i.e. cropping year. Across the years relative ranking of the genotypes changes which resulted significant crops interaction. The genotype and yearswere not significant for all the traits except tilleringshowing that the mean performance of the genotypes was similar over the year suggesting locational trials rather than the years (Chang, 1996).

A varietal improvement program depends on the genetic variability present in a population. The amount 
of genetic variation for a trait present in a genotype can beefficiently estimated by heritability (Chaudhary, 2001). High broad sense heritability estimates were obtained for internodes length (43\%), cane yield (41\%), cane length (39\%), number of nodes (39\%) and number of millablecane (35\%) (Table 4).It is evident that some proportion of the total variance is heritable and these traits must be given importance during selection. The study showed thatinternodes length, cane length and number of nodes were reliable selection parameters.

Both heritability and genetic gain made the selection process effective (Shoba et al., 2009). The high genetic gain observed for cane length $(36.53 \mathrm{~cm})$ followed by plant height $(31.84 \mathrm{~cm})$ and number of tillers per $9 \mathrm{~m}^{2}$ (12.84) was the result of high broad sense heritability for these traits (Bakshi, 2005). These results suggest that considerable scope for improvement in these traits is present. High genetic advance has also been reported for single stalk weight and number of millablecane by Tyagi and Singh, (1998), Kamat and Singh (2001). Gravois and Milligan (1992) found that single stalk weight and number of millablecane gave larger value for broad sense heritability suggesting that these traits are under the control of additive genetic effects.

The strong genetic correlation between agronomic traits suggests that selection of these traits could simultaneously improve these traits. Sanghera et al. (2015) found positive phenotypic and genotypic correlation of different morphological and cane characters with cane yield. Cane length and weight, number of nodes and internodes length were positively and substantially correlated with cane yield as reported by Chaudhary et al. (2003).

\section{Conclusions}

This study revealed genetic and phenotypic association of cane yieldwith different parameters. Due to diverse background sufficient variability were present among the genotypes. The results suggest that assessment of sugarcane genotypes for cane yield in the plant crop in many years should identify superior clones. This testing approach coupled with a selection strategy based on internodes length, number of nodes, cane length, number of millablecane and plant height might result in significant genetic improvement in cane yield on the basis of higher heritability and genetic gain.

\section{Author's Contribution}

The manuscript was the part of $\mathrm{PhD}$ thesis of Amjad Ali and Sher Aslam Khan supervise him. Abid Farid critically reviewed the first draft. Ayub Khan helped in compilation of results. Shah Masud Khan helped in relevant literature search. Naushad Ali helped during fieldwork.

\section{References}

Arain, M.Y., R.N. Panhwar, N. Gujar, M. Chohan, M.A. Rajput, A.F. Soomro and S. Junejo. 2011. Evaluation of new candidate sugarcane varieties for some qualitative and quantitative traits under Thatta agro-climatic conditions. J. Anim. Plant Sci. 21(2):226-230.

Bakshi, R. 2005. Estimation of genetic parameters in different environments and their implications in sugarcane breeding. Indian J. Genet. 65(3):219-220.

Baloch, S.M., I.H. Shah, I.Hussain and K.Abdullah. 2002. Low sugar production in Pakistan Causes and Remedies. Pak. Sugar. J. 17(5):1314.

Chang, Y.S. 1996. Estimating heritability of and correlations among brix, purity and sugar content in sugarcane using balanced multiple location and year data. Taiwan Suga. Res. Inst. 151:1-10.

Chaudhary, R.R., N.K. Chaudhary and R.C. Sharma 2003. Path coefficient analysis in sugarcane. J. Inst. Agric. Anim. Sci. 24: 13-19.

Chaudhary, R.R. 2001. Genetic variability and heritability in sugarcane. Nepal Agric. Res. J. 4:5659.

Falcon, W.P. 1964. Farmer response to price in a subsistence economy: The case of West Pakistan. Am. Eco. Review. 54(3): 580-591.

Gravois, K.A. and S.B. Milligan. 1992. Genetic relationship between fiber and sugarcane yield components. Crop Sci. 32(1): 62-67. https://doi.org/10.2135/cropsci1992.0011183X003200010014x

Jamoza, J.E., Owuoche, J., Kiplagat, O. and Opile, W. 2014. Broad-sense heritability estimation and correlation among sugarcane (Saccharum $s p p$. hybrids) yield and some agronomic traits in western Kenya. Int. J. Agric. Pol. Res. 2(1):16- 
25.

Johnson, H.W., H.F. Robinson and R.F. Comstock. 1955. Estimates of genetic and environmental variability in Soyabean. Agron. J. 47: 314-318. https://doi.org/10.2134/agronj1955.00021962 004700070009x

Kamat, D.N. and J.R.P. Singh. 2001. Variability in sugarcane under rainfed conditions. Sugar Tech. 3:65-67. https://doi.org/10.1007/BF02945535

Kang, M.S., J.D. Miller and P.Y.P. Tai. 1983. Genetic and phenotypic path analyses and heritability in sugarcane. Crop Sci. 23(4): 643-647. https://doi.org/10.2135/cropsci1983.0011183X002300040010x

Khan, I.A., M.U. Dahot, N. Seema, S. Yasmin, S. Bibi, S. Raza and A. Khatri. 2009. Genetic variability in sugarcane plantlets developed through in vitro mutagenesis. Pak. J. Biot. 41(1):153166.

Khan I.A., A. Khatari, M.A. Siddiqui, G.S. Nizamani and S. Raza. 2004. Performance of promising sugarcane clones for yield and quality in different ecological zones of Sindh. Pak. J. Bot. 36(1): 83-92.

Mode, C.J. and H.F. Robinson. 1959. Pleiotropism and the genetic variance and covariance. Biometrics. 15(4): 518-537. https://doi. org $/ 10.2307 / 2527650$

Poehlman, J.M. 1959. Breeding Asian field crops. Publisher, New Delhi, Oxford Ibh Publishing Co.

Punia, M.S. 1982. Studies on variability, heritability and genetic advance of some quality attributes in sugarcane. Indian Sugar. 31: 911-914.

Sanghera, G.S., V.Tyagi, R. Kumar, K.S. Thind and
B. Sharma. 2015. Genetic variability, association and their dissection through path analysis for cane yield and its component traits in early maturing sugarcane clones. J. Sci. Agric. 5(1): 28-34.

Shoba, D., N. Manivannan and P. Vindhiyavarman. 2009. Studies on variability, heritability and genetic advance in groundnut (Arachis bypogeal L.). Electronic J. Plant Breed. 1(1): 74-77.

Singh, M.S., Ceccarelli and J. Hamblin. 1993. Estimation of heritability from variety trial data. Appl. Genet. 86: 437-441. https://doi. org/10.1007/BF00838558

Tahir, M., H. Rahman, A. Ali, S. Anwar and M. Khalid. 2013. Assessment of genotype x environment interaction and stability of promising sugarcane genotypes for different agronomic characters in Peshawar valley. Am. J. Exp. Agric. 3(1):142-151. https://doi.org/10.9734/ AJEA/2013/2282

Tahir, M., I.H. Khalil, P.H. M. Cord and B. Glazz. 2014a. Character association and selection indices in sugarcane. Am. J. Exp. Agric. 4(3): 336348.https://doi.org/10.9734/AJEA/2014/6086

Tahir, M., I.H. Khalil, P.H.Mc Cord, B. Glazand J. and Todd. 2014b. Phenotypic selection of sugarcane genotypes using best linear unbiased predictors. J. Am. Soc. Sugarcane Tech. 34:4456.

Tyagi, S.D. and D.N. Singh. 1998. Studies on genetic variability for stalk characters in sugarcane. Indian Sugar. 48(4): 259-262.

Utz H.F. 2011. A computer program for statistical analysis of plant breeding experiments Version $3 \mathrm{~A}$ of 2011. 